\title{
Nucleocapsid Gene-Mediated Transgenic Resistance Provides Protection Against Tomato spotted wilt virus Epidemics in the Field
}

\author{
Sonia Herrero, Albert K. Culbreath, Alex S. Csinos, Hanu R. Pappu, Rebeca C. Rufty, and Margaret E. Daub
}

First and sixth authors: Department of Plant Pathology, P.O. Box 7616, North Carolina State University, Raleigh 27695-7616; second, third, and fourth authors: Department of Plant Pathology, P.O. Box 748, University of Georgia-Coastal Plain Experiment Station, Tifton 317930748; and fifth author: Crop Science Department, North Carolina State University, P.O. Box 7620 Raleigh 27695-7620. Accepted for publication 13 October 1999.

\begin{abstract}
Herrero, S., Culbreath, A. K., Csinos, A. S., Pappu, H. R., Rufty, R. B., and Daub, M. E. 2000. Nucleocapsid gene-mediated transgenic resistance provides protection against Tomato spotted wilt virus epidemics in the field. Phytopathology 90:139-147.

Transformation of plants with the nucleocapsid (N) gene of Tomato spotted wilt tospovirus (TSWV) provides resistance to disease development; however, information is lacking on the response of plants to natural inoculum in the field. Three tobacco cultivars were transformed with the $\mathrm{N}$ gene of a dahlia isolate of TSWV (TSWV-D), and plants were evaluated over several generations in the greenhouse. The resistant phenotype was more frequently observed in 'Burley 21 ' than in 'KY-14' or ' $\mathrm{K}-326$ ', but highly resistant 'Burley 21 ' transgenic lines were resistant to only $44 \%$ of the heterologous TSWV isolates tested. Advanced generation $\left(\mathrm{R}_{3}\right.$ and $\mathrm{R}_{4}$ ) transgenic resistant lines of 'Burley 21' and a 'K-326' $\mathrm{F}_{1}$ hybrid containing the $\mathrm{N}$ genes of two TSWV isolates were evaluated in the field near Tifton, GA, where TSWV is endemic. Disease development was

monitored by symptom expression and enzyme-linked immunosorbent assay (ELISA) analysis. Whereas incidence of TSWV infection in 'Burley 21 ' susceptible controls was $20 \%$ in 1996 and $62 \%$ in 1997, the mean incidence in transgenic lines was reduced to 4 and $31 \%$, respectively. Three transgenic 'Burley 21 ' lines were identified that had significantly lower incidence of disease than susceptible controls over the two years of the study. In addition, the rate of disease increase at the onset of the 1997 epidemic was reduced for all the 'Burley 21' transgenic lines compared with the susceptible controls. The ' $\mathrm{K}-326$ ' $\mathrm{F}_{1}$ hybrid was as susceptible as the ' $\mathrm{K}$ 326 ' nontransformed control. ELISA analysis demonstrated that symptomless plants from the most resistant 'Burley 21' transgenic lines accumulated detectable nucleocapsid protein, whereas symptomless plants from more susceptible lines did not. We conclude that transgenic resistance to TSWV is effective in reducing incidence of the disease in the field, and that accumulation of transgene protein may be important in broad-spectrum resistance.
\end{abstract}

Tomato spotted wilt tospovirus (TSWV) belongs the TSWV serogroup (formerly serogroup I) of the genus Tospovirus. Viral particles are composed of three single-stranded RNA molecules of negative or ambisense polarity that are bound to nucleocapsid protein units. These ribonucleoprotein complexes and the putative RNA-dependent RNA polymerase are enclosed in a glycoprotein envelope. TSWV has been reported worldwide in a large number of host species belonging mostly to the Solanaceae and the Compositae families and can be transmitted by six species of thrips (Thysanoptera: Thripidae). The most important vector worldwide in TSWV epidemics is the western flower thrips, Frankliniella occidentalis (Pergande), which can transmit various TSWV strains $(9,21,40)$. In Georgia, F. fusca Hinds, the tobacco thrips, is the most important vector species on tobacco (19).

Field crops such as peanut and tobacco have been severely affected by TSWV over the last two decades across the southern United States. Texas was the first state to report the presence of TSWV in peanut fields in 1974 (13). The virus was detected in 1986 in Georgia in tobacco fields (5). The disease is now considered endemic in the southern United States, and field epidemics are causing considerable economic losses worldwide (12). Effective management of TSWV in field crops has proved difficult due to the ineffectiveness of available management practices and the lack of durable or transferable natural host resistance. Chemical control of the vector to limit transmission and spread of TSWV is

Corresponding author: M. E. Daub; E-mail address: margaret_daub@ncsu.edu

Publication no. P-1999-1203-01R

(C) 2000 The American Phytopathological Society inadequate $(32,38)$. Cultivar resistance to thrips feeding is very limited and not readily available in all systems (28). The most desirable control measure is the use of genetic resistance. A few sources of resistance to TSWV have been identified and are being incorporated into commercial cultivars of lettuce, tomato, and pepper $(2,4,16)$. However, strains have been found that overcome natural resistance conferred by a single dominant gene ( $\mathrm{Sw}-5)$ in tomato cv. Stevens $(4,37)$. In tobacco, natural resistance is scarce. The only known source of high levels of resistance to TSWV is European tobacco cv. Polalta, but incorporation of such resistance into North American tobacco cultivars has been difficult because resistant progeny derived from crosses are phenotypically abnormal (14).

Pathogen-derived resistance constitutes a novel strategy for developing resistance to plant viruses. Transgenic resistance to TSWV was first engineered by introducing the TSWV nucleocapsid $(\mathrm{N})$ gene into tobacco $(10,17)$. Since that time, a large number of studies have reported on the isolation of TSWV-resistant plants in crops such as tomato, lettuce, and chrysanthemum, all transformed with the TSWV N gene $(15,24,34)$. Research on TSWV transgenic resistance has centered mostly on the analysis of $R_{0}$ and $R_{1}$ plants, and there is a lack of information on the stability of the resistance response through generations. Furthermore, transgenic resistance to TSWV has been shown to be strain-specific and may not hold against isolates distinct from the homologous source of the transgene $(23,26,41)$. The specificity of TSWV transgenic resistance, coupled with the vast diversity found among natural TSWV strains and the rapidity with which they arise $(20,22)$, raises questions about the utility and stability of transgene resistance in the field. Genomic reassortants of TSWV have been isolated and found to overcome transgenic resistance in tobacco (31). Strain variability 
may account for the scarcity and lack of durability of natural sources of resistance to this virus (12).

Only a few transgenic crops susceptible to positive-sense RNA plant viruses have been evaluated for resistance under field conditions. In most instances, plants were mechanically inoculated with specific strains of the virus. Although immunity has not been observed under field conditions, variable degrees of resistance have been reported for potyviruses and cucumoviruses $(35,39,42)$. There is only one publication on field evaluation of transgenic tobacco for resistance to TSWV (36). Given the diversity of TSWV strains and the narrow spectrum of resistance in $\mathrm{N}$-gene transformed plants, information is needed on the stability and spectrum of resistance under natural inoculum conditions in the field. Here we report on a 2-year field study of advanced-generation tobacco lines exposed to natural inoculum from volunteer peanut plants in a field where TSWV is endemic. Transgenic lines were identified that had significantly reduced incidence of infection by the diversity of TSWV strains at the field site. These results indicate that genetically engineered virus resistance constitutes an effective approach to reduce the severity of TSWV epidemics in tobacco. However, the cultivar to be transformed constitutes an important component of successful implementation of transgenic resistance for TSWV control.

\section{MATERIALS AND METHODS}

Gene constructs. Four constructs of the $\mathrm{N}$ gene of a dahlia TSWV isolate (TSWV-D, GenBank Accession no. AF020660) were used for tobacco transformations. Constructs pTSWVN+ $(\mathrm{N}+)$, pTSWVNt $(\mathrm{Nt})$, and pTSWVN- $(\mathrm{N}-)$ have been previously described (34). They contain a full-length $\mathrm{N}$ gene encoding a wildtype 29-kDa nucleocapsid protein $(\mathrm{N}+)$, a full-length $\mathrm{N}$ copy that translates into a $27-\mathrm{kDa}$ truncated protein $(\mathrm{Nt})$, and an antisense version of the $\mathrm{N}$ gene $(\mathrm{N}-)$. To engineer the fourth construct $(\mathrm{N}++)$, the $\mathrm{N}$ gene contained in plasmid pTSWVN+ was amplified by polymerase chain reaction (PCR) with primers 5'-GCTCTAGAGCTTTCAAGCAAGTTCTGCG-3' and 5'-CCAAGCTTCCCATCATGCTAAGGTTAAGCTCA C-3'. The PCR fragment was subcloned into a HindIII-XbaI site of the transformation vector pKYLX71-35S $\mathrm{S}^{2}$ (33), where expression of the $\mathrm{N}$ gene is driven by a modified $35 \mathrm{~S}$ CaMV promoter containing two copies of the enhancer element. The resulting plasmid, pTSWVN++, was maintained in Escherichia coli strain DH5 $\alpha$ and transferred into Agrobacterium tumefaciens strain LB4404 (ClonTech Laboratories Inc., Palo Alto, CA) by the methods of An (1).

Tobacco transformations and selection. Three cultivars were used: Burley 21 and KY-14, both burley types; and K-326, a fluecured type. 'Burley 21' plants were separately transformed with

TABLE 1. Reaction of 'Burley 21' transgenic tobacco to different Tomato spotted wilt virus (TSWV) isolates

\begin{tabular}{lllc}
\hline Isolate $^{\mathrm{a}}$ & \multicolumn{1}{c}{ Host } & \multicolumn{1}{c}{ Origin } & Resistant $^{\mathrm{b}}$ \\
\hline TSWV-D & Dahlia & Netherlands & + \\
TSWV-A & Tobacco & North Carolina & - \\
TSWV-B & Tobacco & North Carolina & - \\
TSWV-C & Tobacco & North Carolina & - \\
TSWV-GT & Tomato & Georgia & - \\
TSWV-GB & Chrysanthemum & North Carolina & + \\
1991-11 & Peanut & Georgia & - \\
1991-26 & Peanut & North Carolina & + \\
1991-31 & Peanut & Texas & + \\
1991-p2 & Peanut & Not available & + \\
\hline
\end{tabular}

a Nine heterologous isolates collected from infected hosts across the southern United States were used to inoculate plants of two Nt-transformed 'Burley 21' lines at the $\mathrm{R}_{3}$ generation.

b + Indicates more than $40 \%$ of inoculated plants within a line lacked systemic infection; - indicates less than $40 \%$ of inoculated plants within a line lacked systemic infection.

c Homologous isolate. all four constructs $(\mathrm{N}+, \mathrm{Nt}, \mathrm{N}-$, or $\mathrm{N}++)$, 'K-326' was transformed with three constructs $(\mathrm{N}+, \mathrm{Nt}$, or $\mathrm{N}++)$, and ' $\mathrm{KY}-14$ ' was transformed with two constructs ( $\mathrm{Nt}$ or $\mathrm{N}++$ ). Transformation of tobacco leaf disks and shoot regeneration was carried out as previously described (6). Shoots were selected and rooted in media containing kanamycin at $50 \mu \mathrm{g} / \mathrm{ml}$ and transplanted into soil pots for TSWV-resistance evaluation.

For evaluation of advanced generations, seeds were collected from TSWV-resistant plants at the $\mathrm{R}_{0}, \mathrm{R}_{1}$, and $\mathrm{R}_{2}$ generations. All seed were surface-sterilized and germinated on hormone-free medium containing kanamycin at $50 \mu \mathrm{g} / \mathrm{ml}$ as previously described (6). Seeds were allowed to grow for 5 to 7 weeks at $25^{\circ} \mathrm{C}$ in a growth chamber, and seedlings that survived kanamycin selection were used for inoculation tests.

Greenhouse screening. All $\mathrm{R}_{0}$ transformants and, in subsequent generations, at least 12 kanamycin-resistant plants per TSWVresistant tobacco line were transferred to the greenhouse and grown for 5 weeks before inoculation. Unless otherwise indicated, plants were inoculated with the homologous dahlia isolate TSWV-D. Plants were mechanically inoculated using a 1:10 dilution $(1 \mathrm{~g}$ of TSWV-infected Nicotiana benthamiana Domin. tissue per $10 \mathrm{ml}$ of buffer; $0.01 \mathrm{M}$ Tris, $\mathrm{pH} 7.8,0.01 \mathrm{M}$ sodium sulfite, and $0.1 \%$ cysteine $\mathrm{HCl}$ ). Inoculation tests for 'Burley 21' and 'KY-14' were performed under greenhouse conditions. 'K-326' plants were incubated in an $18^{\circ} \mathrm{C}$ growth chamber 2 days before inoculation and remained there until the appearance of systemic symptoms on susceptible controls, after which all plants were moved to the greenhouse. For selection and advancement of resistant lines, seeds were harvested only from plants that lacked any systemic symptoms.

For testing resistance to heterologous isolates of TSWV, isolates from tobacco, peanut, and chrysanthemum were used (Table 1). These isolates were maintained as previously described (31), and inoculations were performed as described above on two Nt-transformed 'Burley 21' lines that were resistant to TSWV-D. We also evaluated a 'K-326' $F_{1}$ hybrid. $F_{1}$ hybrid seed was obtained from a cross between a resistant $R_{3}$ plant from line 2A-3-3 transformed with the $\mathrm{N}+$ construct from TSWV-D, and a resistant plant from line F-06 transformed with the $\mathrm{N}$ gene from a Hawaiian TSWV isolate (TSWV-L) (15). Line F-06 is a doubled haploid line provided by E. A. Wernsman (Crop Science Department, North Carolina State University, Raleigh) and was used as a female parent. The hybrid and the 'K-326' parental lines (F-06 and 2A-3-3) were evaluated for their ability to confer resistance to the two homologous isolates TSWV-D and TSWV-L.

Field evaluation. A total of six advanced 'Burley 21' transgenic tobacco lines, including two lines derived from plants transformed with the $\mathrm{Nt}$ construct (Nt/47-2-2-2 and Nt/11-11-14), two with the $\mathrm{N}+$ construct $(\mathrm{N}+8-2-2$ and $\mathrm{N}+/ 7-6-10)$, and two with the $\mathrm{N}-$ construct (N-/45-8-7 and N-/12-9-1), were selected for field evaluation in 1996 and 1997. All lines were evaluated at the $R_{3}$ generation except line $\mathrm{Nt} / 47-2-2-2$, which was evaluated at the $R_{4}$. Additionally, the 'K-326' $\mathrm{F}_{1}$ hybrid (F-06 $\left.\times 2 \mathrm{~A}-3-3\right)$ was tested in 1997. The Polish cv. Polalta was used as a resistant control. Susceptible controls included nontransformed 'Burley 21', 'Burley 21' transformed with the plasmid vector $\mathrm{pBI} 121$, and 'K-326' (only tested in 1997).

Seedlings from all entries were grown in the greenhouse for 1.5 months before they were transported to the Coastal Plain Experiment Station in Tifton, GA. The experiment was carried out during two consecutive years in the same field. TSWV and thrips vectors (F. fusca and $F$. occidentalis) were endemic in the field, and no additional thrips or virus were introduced into plots. Planting dates were 2 May 1996 and 28 March 1997. Plot sizes were 13 plants per plot and 15 plants per plot, respectively, for 1996 and 1997. Plots were planted in a randomized complete block design with six replications according to standard cultivation practices. To increase inoculum pressure, rows of volunteer peanuts and weeds that were naturally infected with TSWV during the previous season were 
alternated with rows of test plants. Disease incidence was determined at eight and four dates during the 1996 and 1997 growing seasons, respectively. Incidence was determined based on symptom expression (1996 and 1997) and by enzyme-linked immunosorbent assay (ELISA) analysis (1997). Due to low TSWV incidence in 1996, tobacco stalks were cut $0.3 \mathrm{~m}$ aboveground on 9 July 1996, and final incidence was recorded from symptoms on sucker regrowth on 9 September 1996. In 1997, final incidence was recorded at the peak of the epidemic on 24 June. The data were analyzed using analysis of variance (ANOVA), and mean comparisons were made using least significant differences $(P=$ 0.05) (ANOVA-SAS; SAS Institute Inc., Cary, NC).

ELISA analysis. Samples of diseased and healthy field plants were evaluated in 1997 for viral protein accumulation to confirm virus identification. Leaf tissue from five symptomatic plants and five symptomless plants per plot were collected on 17 June 1997. A diagnostic TSWV kit from Agdia (Elkhart, IN) was used to perform double-antibody sandwich (DAS) ELISA tests. TSWV N protein accumulation was estimated by reading microtiter plates at an optical density of $490 \mathrm{~nm}\left(\mathrm{OD}_{490}\right)$. Reactions with either $\mathrm{OD}_{490}$ values $\geq 0.1$ or three standard deviations greater than the mean of the healthy control were scored as positive.
Southern analysis. Three greenhouse-grown plants from transgenic lines evaluated in the field and two plants from ' $\mathrm{K}-326$ ' parental lines F-06 and 2A-3-3 were subjected to Southern blot analysis to confirm the presence of the transgene and to estimate the number of insertion sites. A total of $15 \mu \mathrm{g}$ of plant DNA was extracted (7) and digested with HindIII, which does not cut within the coding region of the $\mathrm{N}$ gene. The $\mathrm{N}$ gene probe was amplified by PCR with primers, as described by Sherman et al. (34), and contained the entire $\mathrm{N}$ gene coding region (nt -4 to 781 ). Transfer of DNA and hybridization with the radiolabeled $\mathrm{N}$ gene probe were carried out according to the membrane manufacturer's protocol (Micron Separations Inc., Westborough, MA), except prehybridization and hybridization steps, which were done at $60^{\circ} \mathrm{C}$.

\section{RESULTS}

Greenhouse screening. Transgenic tobacco $\mathrm{R}_{0}$ regenerants of 'Burley 21', 'KY-14', and 'K-326' were obtained from each of the transformation experiments. When inoculated with TSWV-D, all plants developed local lesions on the inoculated leaves after 6 to 10 days, depending on the experiment. On average, systemic symptoms appeared 12 to 16 days after inoculation. Four phenotypes
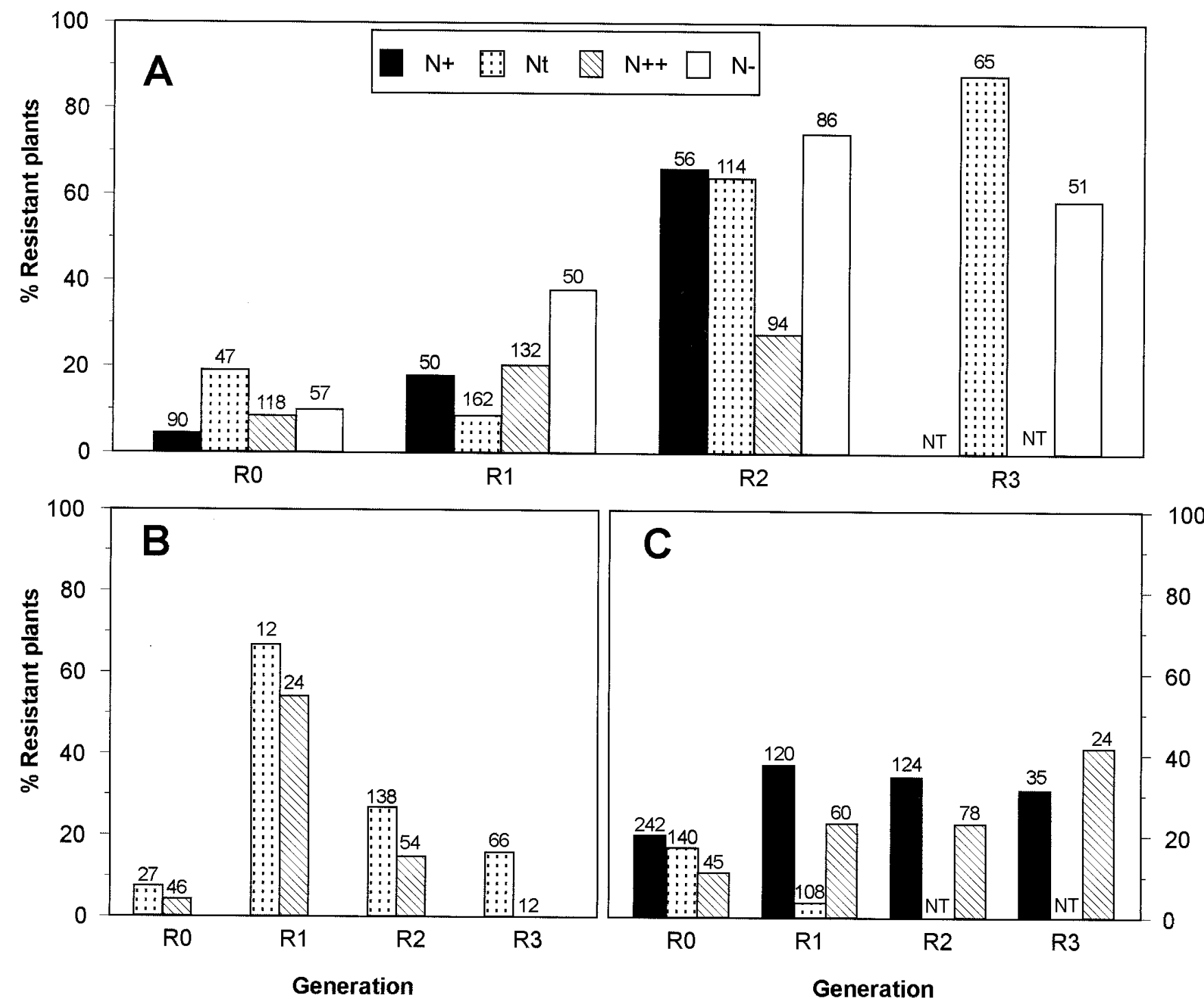

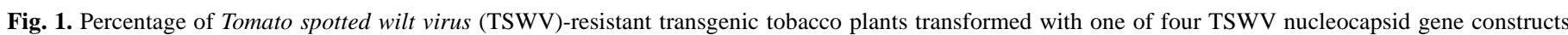

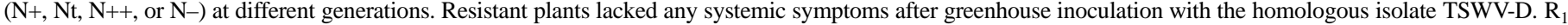

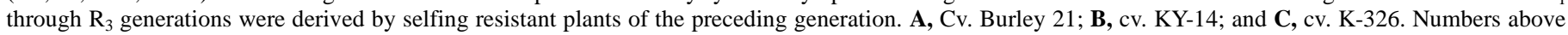

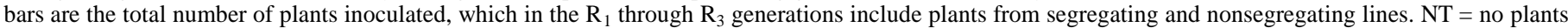
tested at that generation. A number with no bar indicates that all plants tested were susceptible to infection. 
were identified: (i) lack of systemic movement of the virus, (ii) systemic infection followed by a subsequent recovery of new growth, (iii) delayed systemic infection, and (iv) fully systemic infection. For the purpose of advancing resistant lines, we chose to categorize as resistant only those plants that lacked any systemic symptoms.

Seed was collected from selfed plants that showed no systemic symptoms after inoculation. In the $\mathrm{R}_{1}, \mathrm{R}_{2}$, and $\mathrm{R}_{3}$ generations, an average performance for each cultivar-construct combination was calculated by pooling the number of resistant plants obtained across the multiple lines tested (Fig. 1). The percentages of 'Burley 21' $\mathrm{R}_{0}$ transformants resistant to TSWV-D ranged from 4 to $19 \%$, depending on the construct (Fig. 1A). When progeny from resistant plants were screened in subsequent generations, by the $\mathrm{R}_{2}$ generation the percentage of resistant $\mathrm{Nt}, \mathrm{N}+$, or $\mathrm{N}-$ plants increased to between 64 and $74 \%$ but only to $28 \%$ for $\mathrm{N}++$ transformed lines. Two 'Burley 21' lines transformed with the Nt construct and one line transformed with the $\mathrm{N}$ - construct were advanced and tested at the $\mathrm{R}_{3}$ generation. Plants of lines transformed with the $\mathrm{Nt}$ construct were highly resistant to the TSWV-D isolate $(88 \%$ lacked systemic symptoms). However, a decrease in the percentage of resistant $\mathrm{R}_{3} \mathrm{~N}$ - transgenic plants (59\%) was observed relative to the previous $\mathrm{R}_{2}$ generation.

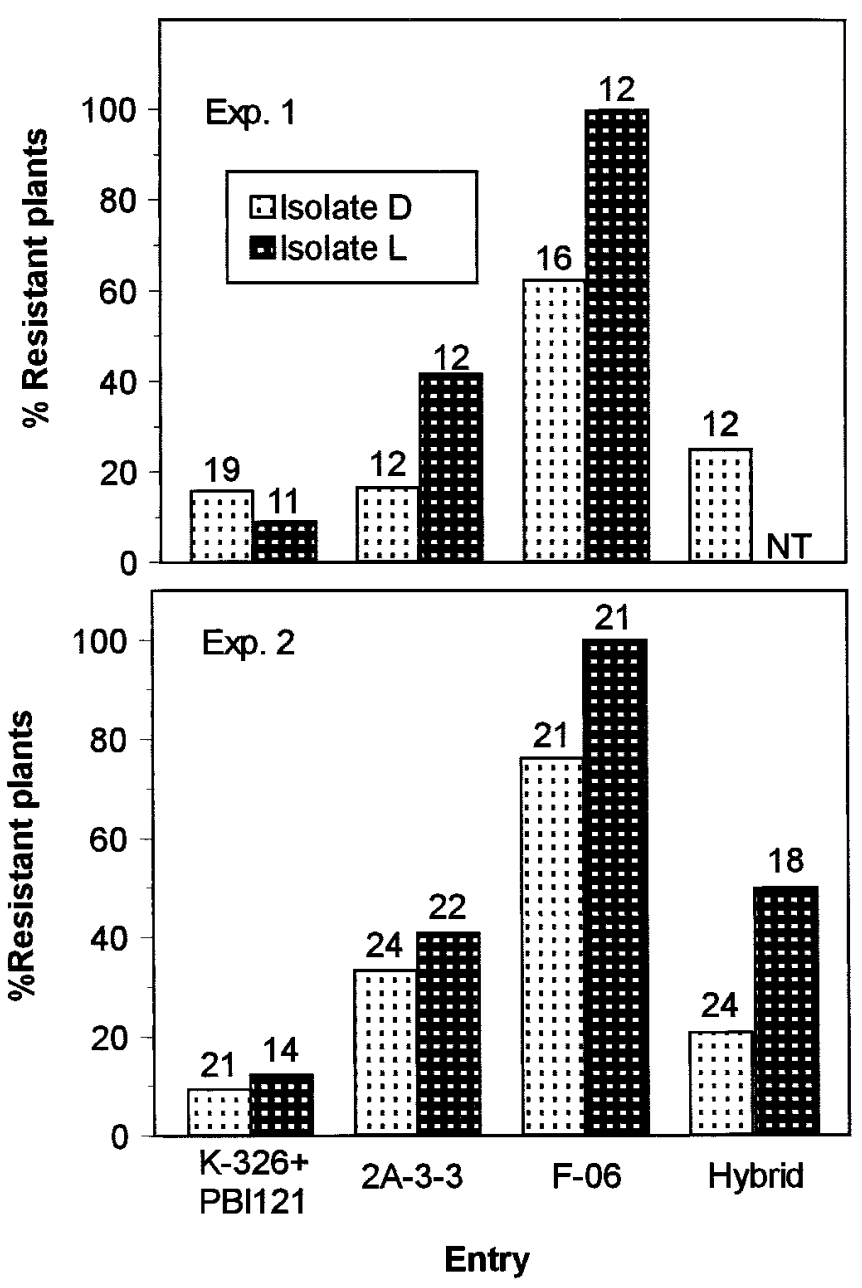

Fig. 2. Percentage of transgenic 'K-326' tobacco plants resistant to Tomato spotted wilt virus (TSWV) isolates D and L in two experiments. Resistant plants had no systemic symptoms or very mild systemic infections. Line 2A3-3 (transformed with the nucleocapsid [N] gene from TSWV-D) was tested at the $\mathrm{R}_{3}$ generation. F-06 is a doubled haploid line transformed with the $\mathrm{N}$ gene from TSWV-L. Hybrid is the $\mathrm{F}_{1}$ hybrid progeny from a cross between a resistant plant of line 2A-3-3 crossed to one from F-06. The susceptible control 'K-326' + PBI121 is 'K-326' transformed with the plasmid vector PBI121. Numbers above bars are the total number of plants inoculated. NT = not tested.
The proportion of $\mathrm{R}_{0}$ plants of 'KY-14' and ' $\mathrm{K}-326$ ' that were resistant to systemic symptom development was comparable to those of 'Burley 21'; however, the resistance did not hold in advanced generations (Fig. $1 \mathrm{~B}$ and $\mathrm{C}$ ). The percentage of resistant 'KY-14' plants increased to 54 to $67 \%$ at the $\mathrm{R}_{1}$ generation. There was a decrease in the percentage of TSWV-resistant plants at the $R_{2}$ and $R_{3}$, indicating that selection of highly resistant transgenic lines was ineffective for 'KY-14'. For 'K-326', there was a moderate increase in the proportion of $\mathrm{N}+-$ and $\mathrm{N}++$-transformed resistant plants in the $\mathrm{R}_{1}$ generation, but further selection yielded no significant increases.

Resistance to heterologous isolates. Two 'Burley 21' Nt-transformed lines that were resistant to TSWV-D were screened at the $\mathrm{R}_{3}$ generation for their ability to confer resistance to a variety of TSWV isolates. In addition to the resistance expressed against the homologous isolate TSWV-D, lines showed resistance to four of nine of the heterologous isolates tested (Table 1). Isolates TSWVGT and 1991-11 overcame the resistance. The N gene of 1991-11 is $95.5 \%$ identical to that of TSWV-D, and of the sequence of TSWV-GT that is available (748 of $777 \mathrm{nt}$ ), $96.6 \%$ is identical to TSWV-D.

A 'K-326' $\mathrm{F}_{1}$ hybrid $(\mathrm{F}-06 \times 2 \mathrm{~A}-3-3)$ and its parents were screened for resistance to the two TSWV isolates (TSWV-D and TSWV-L) used to generate the parental lines (Fig. 2). The $\mathrm{N}$ genes of these two isolates show $97.6 \%$ sequence identity. The parental line F-06 showed the expected resistance to the homologous isolate TSWV-L but also showed good resistance to TSWV-D. Although the 2A-3 $R_{2}$ plant used as a male parent in the cross was resistant and was

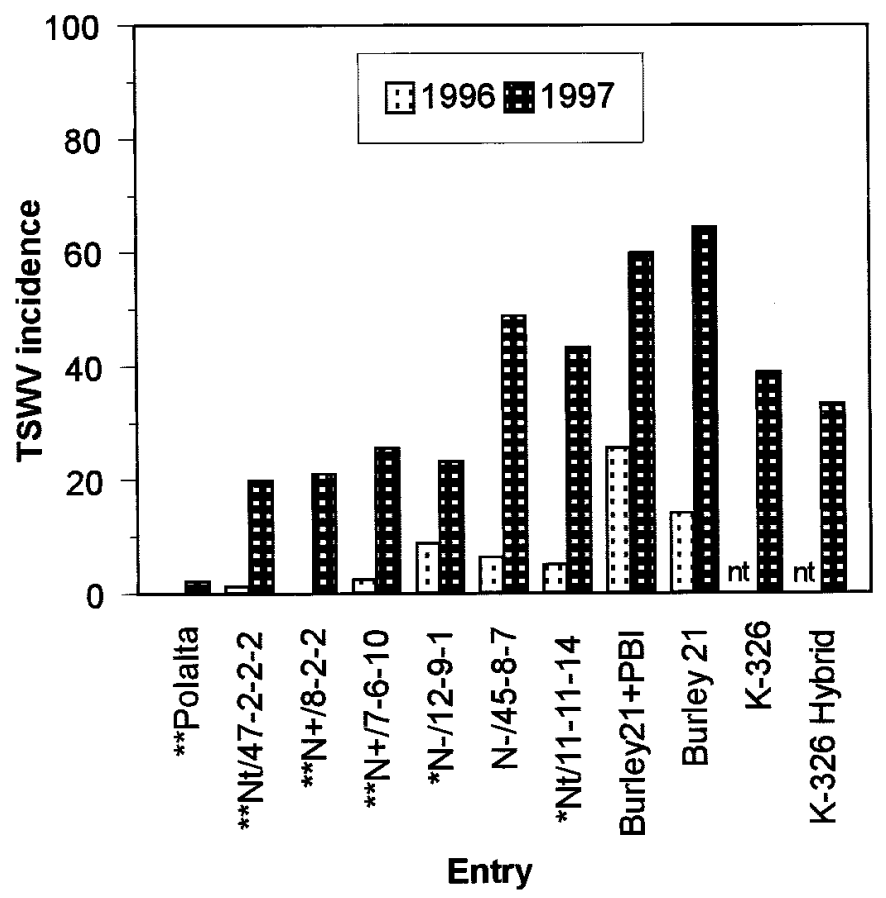

Fig. 3. Final Tomato spotted wilt virus (TSWV) incidence (percent symptomatic plants) in control and transgenic tobacco lines grown in a field at the Coastal Plain Experiment Station, Tifton, GA, in 1996 and 1997 under natural inoculum conditions. Inoculum was provided by spreader rows of volunteer peanuts and weeds that had been naturally infected in 1995 and 1996. Transformed lines: Nt and N+ lines ('Burley 21' transformed with sense constructs); N- lines ('Burley 21' transformed with an antisense construct); and 'K-326' hybrid (hybrid between two 'K-326' transformed lines, each transformed with the nucleocapsid gene of a different isolate of TSWV). Controls are 'Polalta' (resistant) and 'K-326', 'Burley 21', and 'Burley 21' transformed with vector plasmid pBI121 (all susceptible). Missing bars indicate that TSWV incidence was 0 , except for entries ' $\mathrm{K}-326$ ' and 'K-326' hybrid, which were not tested (NT) in 1996. ${ }^{* *}=$ Tobacco lines significantly different from susceptible 'Burley 21' controls in both 1996 and $1997(P=0.05)$. * = Tobacco lines significantly different from susceptible 'Burley 21' controls only in $1997(P=0.05)$. 
derived from a highly resistant $2 \mathrm{~A}-3 \mathrm{R}_{2}$ line $(77 \%$ resistant as an $\mathrm{R}_{2}$ ), high levels of resistance to the homologous isolate TSWV-D were not observed when line $2 \mathrm{~A}-3-3$ was tested at the $\mathrm{R}_{3}$ generation (Fig. 2), and these plants showed a similar low frequency of resistance to TSWV-L . Contrary to expectations, the 'K-326' $\mathrm{F}_{1}$ hybrid $(\mathrm{F}-06 \times 2 \mathrm{~A}-3-3)$ containing $\mathrm{N}$ genes from both TSWV$\mathrm{D}$ and TSWV-L did not show increased protection. The percentage of plants resistant to each isolate was approximately half that shown by the F-06 parental line and was comparable to that of the $2 \mathrm{~A}-3-3 \mathrm{R}_{3}$ parental line.

Field evaluation. The year-genotype interaction was significant and, consequently, data from both seasons were not pooled. This interaction was most likely due to large differences in TSWV incidence between 1996 and 1997. Because of the low disease incidence in 1996, tobacco stalks were cut near the base of the plants and final incidence data were taken on 9 September from suckers that developed from the plants. In the greenhouse, we have noted that sucker regrowth from initially symptomless plants can become symptomatic. In 1996, the final incidence of TSWV on susceptible 'Burley 21' controls was 14 and 26\%, respectively, for 'Burley 21' and 'Burley 21' transformed with vector plasmid pBI121 (Fig. 3). Three transformed 'Burley 21' lines (Nt/47-2-2-2, N+/8-2-2, and $\mathrm{N}+/ 7-6-10)$ had significantly $(P=0.05)$ lower incidence of infection, ranging from 0 to $3 \%$. Highly resistant 'Polalta' showed no virus symptoms throughout the 1996 season. Overall, the rate of disease development in 1996 was higher only for the susceptible 'Burley 21 ' + pBI121 control compared with the transgenic lines (Fig. 4A).

Disease pressure was considerably higher in 1997, and final incidence data were taken at the peak of the epidemic on 24 June. The incidence of TSWV-symptomatic plants reached 60 to $64 \%$ for 'Burley 21' susceptible controls (Fig. 3). Five transgenic 'Burley 21 ' transgenic lines, including the three that had significantly lower incidence in 1996 (Nt/47-2-2-2, N+/8-2-2, N+/7-6-10, N-/12-9-1, and $\mathrm{Nt} / 11-11-14)$, showed significantly $(P=0.05)$ lower incidence of infection from susceptible controls, ranging from 20 to $43 \%$. Resistant 'Polalta' had the lowest incidence of infection at 2\%. In the 1997 season, the 'K-326' $\mathrm{F}_{1}$ hybrid $(\mathrm{F}-06 \times 2 \mathrm{~A}-3-3)$ was included for field evaluation to determine if the presence of two different TSWV N genes would increase the spectrum of resistance. However, disease incidence on the 'K-326' hybrid in the field was not significantly different from the susceptible 'K-326' control (Fig. $3)$. Differences in the rate of disease increase were most apparent in 1997, under high disease pressure (Fig. 4). The rate of disease increase was reduced in 'Polalta' and 'Burley 21' transgenic lines $\mathrm{N}+/ 7-6-10, \mathrm{~N}-/ 12-9-1, \mathrm{~N}+/ 8-2-2$, and Nt/47-2-2-2 (Fig. 4B). No differences were observed between the nontransformed ' $\mathrm{K}-326$ ' and the 'K-326' $\mathrm{F}_{1}$ hybrid (Fig. 4C).

TSWV N protein accumulation. Tissue samples were collected at the peak of the 1997 epidemic and tested for nucleocapsid protein accumulation using an ELISA kit (Table 2). For all transgenic lines, a high proportion of the symptomatic plants were ELISA positive (81 to $100 \%)$. In a few instances, $\mathrm{N}$ protein could not be detected in obviously symptomatic plants, which may have been due to a decrease in virus titers with time after the initial inoculation.

When symptomless plants were assayed, most had no significant protein accumulation; however, some lines ('K-326' $\mathrm{F}_{1}$ hybrid, $\mathrm{Nt} / 47-2-2-2, \mathrm{~N}+/ 7-6-10$, and $\mathrm{N}+/ 8-2-2)$ contained a significant number of plants (14 to $97 \%$ ) that were ELISA positive (Table 2). Among the 'Burley 21' lines, the lines that showed N-protein ac-

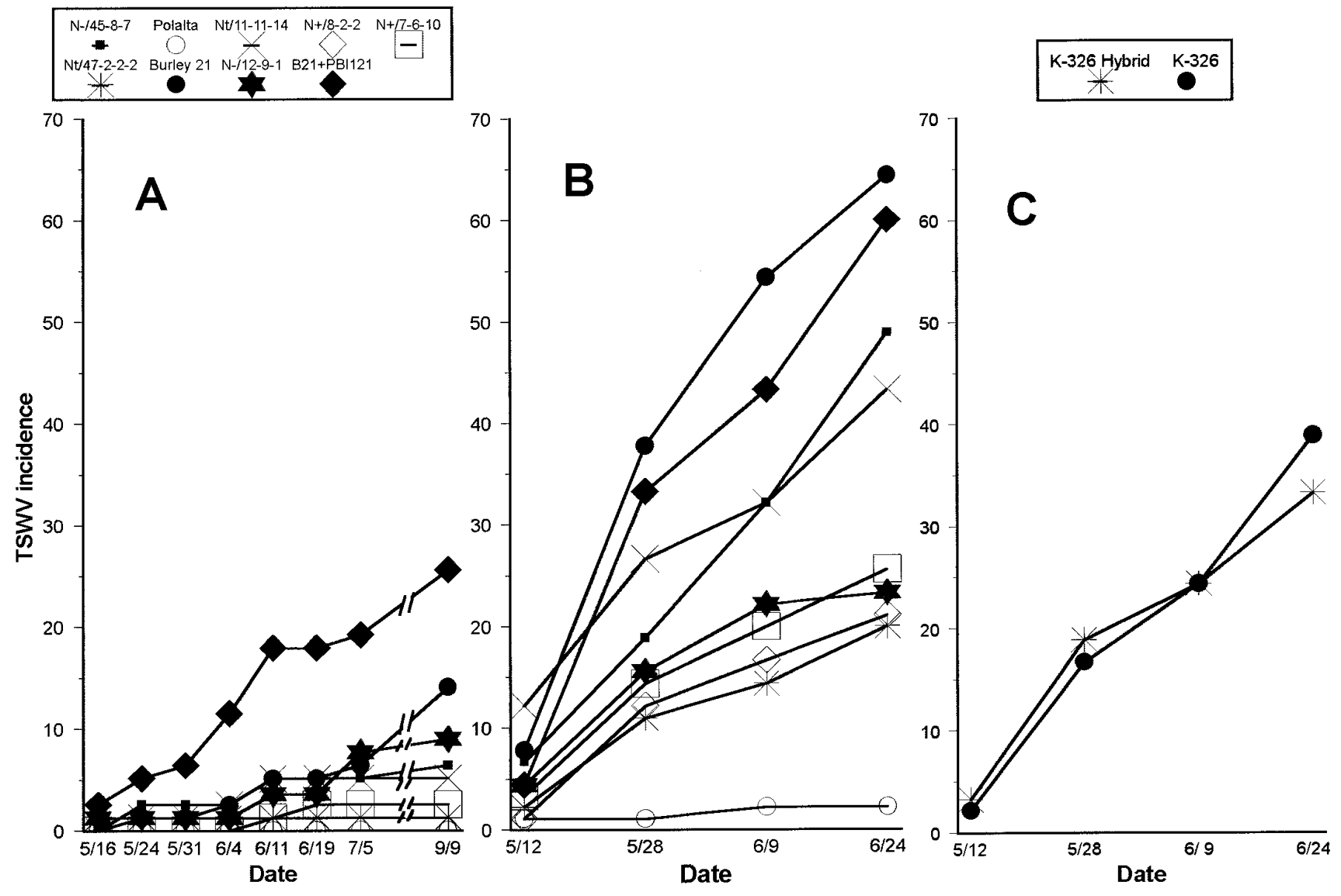

Fig. 4. Disease progress of the Tomato spotted wilt virus (TSWV) epidemic in control and transgenic tobacco in the field. A and B, Control and transgenic lines of cv. Burley 21 in 1996 and 1997, respectively. C, Control cv. K-326 and transgenic 'K-326' hybrid in 1997. Responses of resistant control cv. Polalta in 1996 and 1997 are shown in A and B. In 1996, tobacco plants were topped $0.3 \mathrm{~m}$ above the soil line on 9 July, and final TSWV incidence was recorded on 9 September, based on symptom development in suckers. Final incidence data in 1997 was recorded on 24 June at the peak of the epidemic. 
cumulation in symptomless plants were those that were most resistant to disease. The presence of $\mathrm{N}$ protein in nonsymptomatic 'Polalta' plants can be attributed to latent infection; however, in transgenic lines, $\mathrm{N}$ protein accumulation could be due to viral latent infection or transgene protein accumulation. To clarify whether the $\mathrm{N}$ protein detected in nonsymptomatic transgenic plants was due to nucleocapsid transgene protein expression, we assayed greenhouse-grown seedlings from seed lots used for the field studies. Expression of transgene $\mathrm{N}$ protein was detected only in resistant 'Burley 21' transgenic line Nt/47-2-2-2 and the susceptible ' $\mathrm{K}$ $326^{\prime} \mathrm{F}_{1}$ hybrid $(\mathrm{F}-06 \times 2 \mathrm{~A}-3-3)$ (Table 3$)$.

Southern analysis. Southern blot analysis was conducted on individual plants from lines tested in the field. The number of insertions in plants from all lines varied from two to six, and there was no apparent correlation between the number of insertions and resistance in the field (Fig. 5). Interestingly, some of the lines $\left(\mathrm{N}+/ 8-2-2, \mathrm{Nt} / 47-2-2-2, \mathrm{~N}-145-8-7\right.$, and the 'K-326' $\mathrm{F}_{1}$ hybrid and its 2A-3-3 parent) were segregating for the number of insertions, even though these lines had been selfed for multiple generations. The 'K-326' $\mathrm{F}_{1}$ hybrid, as expected, showed the presence of insertions from each of the parents.

\section{DISCUSSION}

The usefulness of genetically engineered resistance to TSWV depends on the ability to produce transgenic lines that are stable through generations and are resistant to the diversity of TSWV strains present in nature. Resistant plants from a variety of TSWVsusceptible crops have been produced after transformation with either the $\mathrm{N}$ gene or the gene that encodes the putative movement protein $\left(\mathrm{NS}_{\mathrm{M}}\right)(10,17,24,29,34)$. However, the expression of transgenic resistance is influenced by factors such as type of transgene sequences, transgene length and dosage, plant developmental stage, and degree of relatedness between the transgene and the challenging virus $(24,25,27,30)$. In view of the many factors affecting the expression of transgenic resistance to TSWV, we undertook this study to investigate the stability of transgenic resistance over generations and the response of advanced lines to natural inoculum in the field.

In our studies, greenhouse evaluation of a large number of transgenic tobacco lines over several generations revealed that selection for TSWV transgenic resistance was more effective for 'Burley 21 ' than for 'KY-14' or 'K-326'. Thus, our results indicate that cultivar effects may be an important factor to consider when developing transgenic virus resistance that is stable through generations. In a recent publication, engineered resistance to TSWV in tobacco was also evaluated at different generations (36). These researchers were unable to obtain uniformly resistant advanced $\left(\mathrm{R}_{3}\right)$ lines from 3 of 12 tobacco cultivars tested. These results agree with our observations that selection of nonsegregating resistant lines is more difficult for certain tobacco cultivars.

Similar to previous reports $(23,26,41)$, resistance to TSWV in our transgenic lines was limited to certain isolates under greenhouse conditions. Two of the isolates which overcame resistance have $\mathrm{N}$ genes with greater than $95 \%$ homology to the $\mathrm{N}$ gene of TSWV-D; thus, resistance appears to require a significant amount of homology. We had hypothesized that a transformant containing the $\mathrm{N}$ gene of two different TSWV isolates would show a broader spectrum of resistance than transformants containing a single $\mathrm{N}$ gene. Surprisingly, the 'K-326' $F_{1}$ hybrid containing copies of the $\mathrm{N}$ genes of both TSWV-D and TSWV-L did not provide better resistance to natural inoculum. Further, in greenhouse inoculation tests, it was more susceptible than the F-06 parental line. The lack of resistance may be due to several factors. First, the $\mathrm{N}$ genes of TSWV-D and TSWV-L share a high degree of nucleotide identity $(97.6 \%)$, and they may not differ enough to confer resistance to different strains. This hypothesis is supported by our inoculation experiments, which did not show a dramatic difference in the response of each of the two parental lines to the two isolates. Second, the resistance found in parental line 2A-3-3 is apparently unstable, because $77 \%$ of the plants in the $\mathrm{R}_{2}$ generation were resistant, compared with only $31 \%$ in the $\mathrm{R}_{3}$. Finally, in the ' $\mathrm{K}-326$ '

TABLE 3. Enzyme-linked immunosorbent assay detection of Tomato spotted wilt virus $(\mathrm{TSWV})$ nucleocapsid $(\mathrm{N})$ protein accumulation in symptomless field plants and noninoculated greenhouse plants of transgenic tobacco lines with varying field performance ${ }^{\mathrm{a}}$

\begin{tabular}{llcc}
\hline Line & Performance $^{\mathrm{b}}$ & Accumulation $^{\mathrm{c}}$ & Expression $^{\mathrm{d}}$ \\
\hline Polalta & Resistant & + & N/A \\
Burley 21 & Susceptible & - & N/A \\
Burley 21 + PBI & Susceptible & - & N/A \\
N-/12-9-1 & Susceptible & - & N/A \\
N-/45-8-7 & Susceptible & - & N/A \\
N+/7-6-10 & Resistant & + & - \\
N+/8-2-2 & Resistant & + & - \\
Nt/11-11-14 & Susceptible & - & - \\
Nt/47-2-2-2 & Resistant & + & + \\
K326 & Susceptible & - & N/A \\
K326 hybrid & Susceptible & + & + \\
\hline
\end{tabular}

${ }^{a}$ Leaf tissue harvested from symptomless tobacco plants in the field and greenhouse-grown noninoculated plants from different transgenic lines was evaluated for (TSWV) $\mathrm{N}$ protein accumulation.

${ }^{\mathrm{b}}$ Resistant lines were significantly different from susceptible controls $(P=$ 0.05 ) during two consecutive seasons.

${ }^{\mathrm{c}}+$ Indicates $\mathrm{N}$ protein accumulation detected in one or more symptomless field-grown plants from a given line; - indicates protein accumulation not detected.

${ }^{\mathrm{d}}$ Transgene $\mathrm{N}$ protein expression (+) or lack of expression (-) in noninoculated plants grown in the greenhouse. N/A = not applicable due to lack of transgene or transformation with antisense construct.

TABLE 2. Enzyme-linked immunosorbent assay (ELISA) detection of Tomato spotted wilt virus (TSWV) nucleocapsid protein in symptomatic and symptomless tobacco plants in the field ${ }^{\mathrm{a}}$

\begin{tabular}{|c|c|c|c|c|c|c|c|c|}
\hline \multirow[b]{2}{*}{ Line } & \multicolumn{4}{|c|}{ Symptomatic plants ${ }^{\mathrm{b}}$} & \multicolumn{4}{|c|}{ Symptomless plants ${ }^{\mathrm{b}}$} \\
\hline & No. assayed & $\%$ Positive & Mean $\mathrm{OD}_{490}$ & Range $\mathrm{OD}_{490}$ & No. assayed & $\%$ Positive & Mean $\mathrm{OD}_{490}$ & Range $\mathrm{OD}_{490}$ \\
\hline Polalta & 3 & 33 & 2.68 & N/A & 29 & 17 & 0.20 & $0.12-0.39$ \\
\hline Burley 21 & 37 & 100 & 2.72 & $0.14-3.50$ & 22 & 0 & 0.00 & N/A \\
\hline $\mathrm{N}-/ 12-9-1$ & 21 & 95 & 2.06 & $0.10-3.37$ & 31 & 0 & 0.00 & N/A \\
\hline $\mathrm{N}-/ 45-8-7$ & 33 & 97 & 2.71 & $0.31-3.58$ & 28 & 0 & 0.00 & N/A \\
\hline $\mathrm{N}+/ 7-6-10$ & 16 & 94 & 2.54 & $0.30-3.55$ & 31 & 23 & 0.14 & $0.10-0.18$ \\
\hline $\mathrm{N}+/ 8-2-2$ & 21 & 81 & 2.34 & $0.16-3.58$ & 28 & 14 & 0.24 & $0.15-0.39$ \\
\hline K326 & 20 & 90 & 2.54 & $0.21-3.53$ & 25 & 0 & 0.00 & N/A \\
\hline K326 hybrid & 15 & 100 & 2.73 & $1.92-3.47$ & 29 & 97 & 1.51 & $0.13-3.40$ \\
\hline
\end{tabular}

${ }^{a}$ Leaf tissue from a random sample of symptomatic and symptomless field-grown transgenic tobacco plants was collected at the peak of the 1997 epidemic and assayed for accumulation of TSWV nucleocapsid protein by ELISA.

${ }^{b}$ Mean and range values are for ELISA-positive plants sampled. OD = optical density; N/A= not applicable. 
$\mathrm{F}_{1}$ hybrid, all transgene insertions are hemizygous. In an analysis of segregating families derived from hybrids between transgenic and nontransformed tobacco plants, we have shown that, in one family, plants harboring a hemizygous copy of the $\mathrm{N}$ gene are susceptible to TSWV-D, whereas their homozygous counterparts are resistant (S. Herrero, R. C. Rufty, and M. E. Daub, unpublished data); thus, gene dosage may be an important factor in resistance.

The most significant aspect of this work is our demonstration that $\mathrm{N}$ gene-mediated resistance can significantly reduce the inci- dence and rate of development of TSWV epidemics on tobacco under natural inoculum conditions in the field. Three of our lines had significantly reduced incidence in the two years of the study, and provided control under both high (1997) and low (1996) disease pressure. To date, there has only been one other study that looked at field response of TSWV N gene-mediated resistance to tobacco under natural inoculum. Stoeva et al. (36) investigated the response of advanced lines from 12 cultivars of tobacco under natural inoculum conditions in a field in Bulgaria. Contrary to our results,

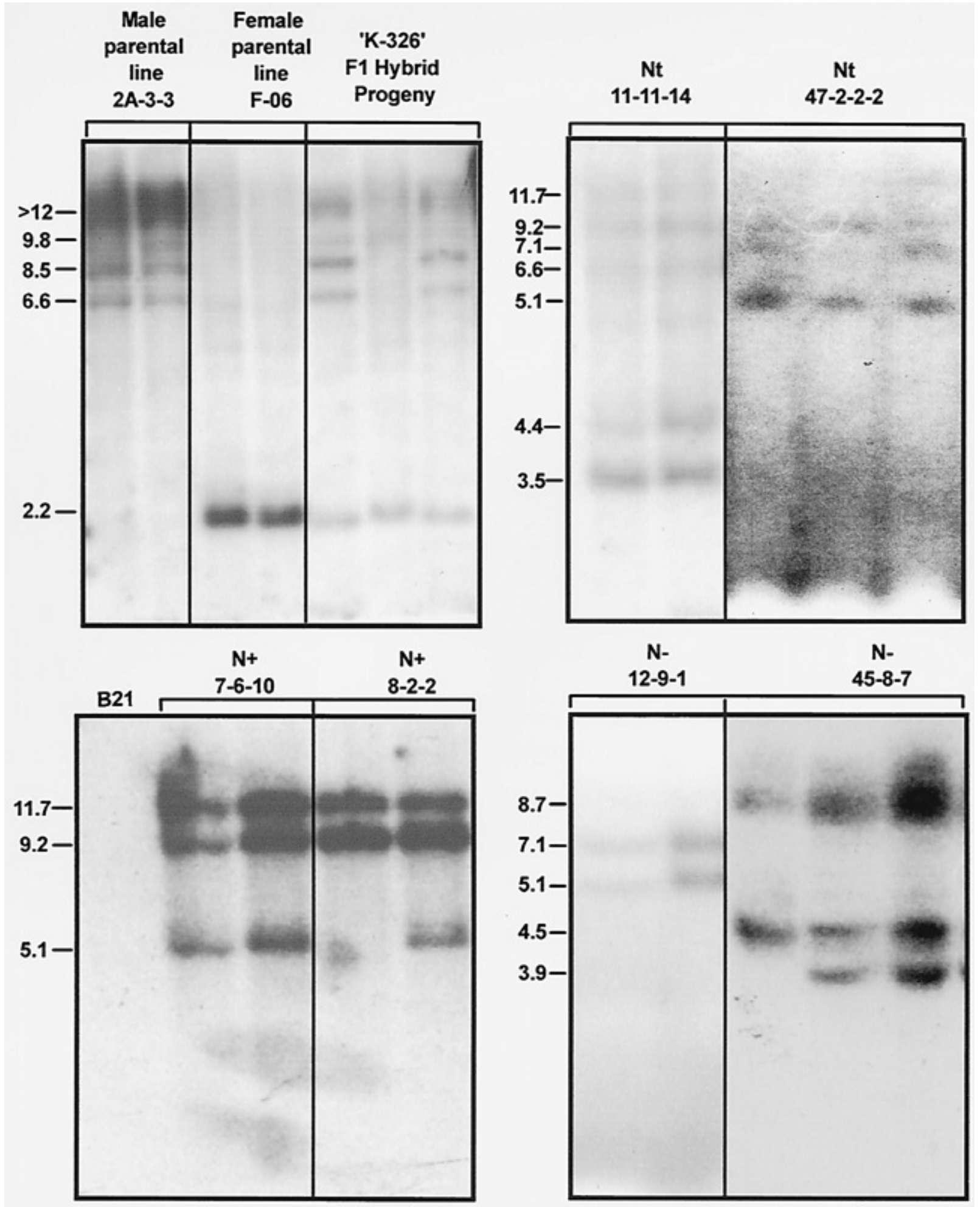

Fig. 5. Southern blot analysis of two to three individual tobacco plants from transgenic lines tested in the field and plants from parental lines (F-06 and $2 \mathrm{~A}-3-3$ ) used to obtain the 'K-326' F1 hybrid. B21 refers to the nontransformed negative control cv. Burley 21. The estimated molecular weight (in kilobases) of each insertion is indicated to the left of each panel. 
Stoeva et al. (36) reported that some of their advanced transgenic tobacco lines were completely resistant to natural TSWV epidemics. This discrepancy between their study and ours may be due to various factors, such as transgene dosage, type of cultivars evaluated, strain diversity present in the field, and disease pressure. None of our transgenic lines was immune to infection, and none exceeded the performance of 'Polalta'. This cultivar would constitute a good source of TSWV resistance, except that severe phenotypic abnormalities (including gross chromosomal aberrations) are found in progeny from crosses between 'Polalta' and American cultivars (14), precluding its use as a parental line in a conventional breeding program.

Our results suggest that transgene protein accumulation, at least with 'Burley 21', may be important for the expression of resistance under field conditions. Only transgenic lines transformed with sense constructs had significantly reduced incidence during the two consecutive seasons. Also, symptomless plants of only the most highly resistant lines showed detectable $\mathrm{N}$ protein accumulation in the field. Detectable N protein could be due to transgene expression or to latent infection. We were only able to confirm transgene expression of one 'Burley 21' line under greenhouse conditions. Also, latent infection is occurring, because $\mathrm{N}$ protein was detected in symptomless plants of 'Polalta'. However, the ability to confer resistance to heterologous TSWV isolates or other tospoviruses has been correlated with transgene protein expression $(23,26,41)$, and our field results are consistent with the hypothesis that protein accumulation is important for broad-spectrum resistance. It is clear, however, that transgene protein accumulation itself is not sufficient for resistance, because the susceptible 'K-326' hybrid had significant $\mathrm{N}$ protein accumulation both in the field and greenhouse screens and was as susceptible as controls.

Finally, our demonstration that transgenic N-gene resistance can significantly reduce TSWV incidence has implications for our understanding of the epidemiology of TSWV epidemics on tobacco. The dynamics and behavior of thrips populations and the role of alternate hosts in TSWV spread are poorly understood for tobacco. In the southeastern United States, the most important vectors of TSWV in field crops are the tobacco thrips, F. fusca, and the western flower thrips, $F$. occidentalis $(3,8,18,19)$. Studies to date suggest that primary spread is caused by viruliferous thrips moving into the field at planting or shortly after, and that secondary plant-to-plant spread is relatively unimportant $(8,11)$. Our results are consistent with these studies. Our transgenic plants are resistant only to a subpopulation of TSWV strains, and TSWV populations are known to readily adapt to resistant cultivars (31). Thus, we would not expect to have seen significant protection if secondary plant-to-plant spread were an important component of the TSWV epidemic. By contrast, in crops such as greenhouse floral crops in which there is significant secondary spread, resistance such as that provided by the TSWV N-gene transgene would not be expected to be effective, because thrips would rapidly spread the resistance-breaking strains. For tobacco, however, we conclude that transgenic resistance to TSWV can be engineered against naturally occurring TSWV strains, and such resistance reduces primary spread of the virus. These measures may constitute an additional and effective control means to manage field epidemics.

\section{ACKNOWLEDGMENTS}

This work was supported by grants from the North Carolina Tobacco Foundation and the North Carolina Tobacco Commission. We thank J. Speck and $\mathrm{J}$. Abad for construction of the $\mathrm{Nt}, \mathrm{N}+$, and $\mathrm{N}$ - constructs and for $\mathrm{N}$ gene sequence information; J. Sherman for synthesis of the N++ construct; R. Perez, E. Faggart, and J.-Y. Tang for assistance with transformation and screening; and S. Geske for assistance with the heterologous isolates.

\section{LITERATURE CITED}

1. An, G., Ebert, P. R., Mitra, A., and Ha, S. B. 1988. Binary vectors. Pages 1-19 in: Plant Molecular Biology Manual. Vol. A3. S. B. Gelvin and R.
A. Schilperoort, eds. Kluwer Academic Publishing, Dordrecht, Netherlands.

2. Boiteux, L. S., Nagata, T., Dutra, W. P., and Fonseca, M. E. N. 1993. Sources of resistance to tomato spotted wilt virus (TSWV) in cultivated and wild species of Capsicum. Euphytica 67:89-94.

3. Chamberlin, J. R., Culbreath, A. K., Todd, J. W., and Demski, J. W. 1993. Detection of tomato spotted wilt virus in tobacco thrips (Thysanoptera: Thripidae) overwintering in harvested peanut fields. J. Econ. Entomol. 86:40-45.

4. Cho, J. J., Custer, D. M., Brommonschenkel, S. H., and Tanksley, S. D. 1996. Conventional breeding: Host-plant resistance and the use of molecular markers to develop resistance to tomato spotted wilt virus in vegetables. Acta Hortic. 431:367-378.

5. Culbreath, A. K., Csinos, A. S., Bertrand, P. F., and Demski, J. W. 1991. Tomato spotted wilt virus epidemic in flue-cured tobacco in Georgia. Plant Dis. 75:483-485.

6. Daub, M. E., Jenns, A. E., Urban, L. A., and Brintle, S. C. 1994. Transformation frequency and foreign gene expression in burley and fluecured cultivars of tobacco. Tob. Sci. 38:51-54.

7. Dellaporta, S. L., Wood, J., and Hicks, J. B. 1983. Maize DNA minipreps. Maize Genet Corp. Newsl. 57:26-29.

8. Eckel, C. S., Cho, K., Walgenbach, J. F., Kennedy, G. G., and Moyer, J. W. 1996. Variation in thrips species composition in field crops and implications for tomato spotted wilt epidemiology in North Carolina. Entomol. Exp. Appl. 78:19-29.

9. German, T. L., Ullman, D. E., and Moyer, J. W. 1992. Tospoviruses: Diagnosis, molecular biology, phylogeny, and vector relationships. Annu. Rev. Phytopathol. 30:315-348.

10. Gielen, J. J. L., de Haan, P., Kool, A. J., Peters, D., van Grinsven, M. Q. J. M., and Goldbach, R. W. 1991. Engineered resistance to tomato spotted wilt virus, a negative-strand RNA virus. Bio/Technology 9:13631367.

11. Gitaitis, R. D., Dowler, C. C., and Chalfant, R. B. 1998. Epidemiology of tomato spotted wilts in pepper and tomato in southern Georgia. Plant Dis. 82:752-756.

12. Goldbach, R. W., and Peters, K. 1994. Possible causes of the emergence of tospovirus diseases. Semin. Virol. 5:113-120.

13. Halliwell, R. S., and Philley, G. 1974. Spotted wilt of peanut in Texas. Plant Dis. Rep. 58:23-25.

14. Kennedy, B. S., and Nielsen, M. T. 1993. Characterization of tomato spotted wilt virus (TSWV) resistance in the tobacco cultivar 'Polalta.' (Abstr.) Phytopathology 83:1420.

15. Kim, J. W., Sun, S. S. M., and German, T. L. 1994. Disease resistance in tobacco and tomato plants transformed with the tomato spotted wilt virus nucleocapsid gene. Plant Dis. 78:615-621.

16. Kumar, N. K. K., Ullman, D. E., and Cho, J. J. 1993. Evaluation of $L y$ copersicon germ plasm for tomato spotted wilt tospovirus resistance by mechanical and thrips transmission. Plant Dis. 77:938-941.

17. MacKenzie, D. J., and Ellis, P. J. 1992. Resistance to tomato spotted wilt virus infection in transgenic tobacco expressing the viral nucleocapsid gene. Mol. Plant-Microbe Interact. 5:34-40.

18. McPherson, R. M., Beshear, R. J., and Culbreath, A. K. 1992. Seasonal abundance of thrips (Thysanoptera: suborders Terebrantia and Tubulifera) in Georgia flue-cured tobacco and impact of management practices on the incidence of tomato spotted wilt virus. J. Entomol. Sci. 27:257-268.

19. McPherson, R. M., Pappu, H. R., and Jones, D. C. 1999. Occurrence of five thrips species on flue-cured tobacco and impact on spotted wilt disease incidence in Georgia. Plant Dis. 83:765-767.

20. Moyer, J. W., and Qiu, W. 1996. Molecular and genetic determinants of diversity in tomato spotted wilt virus. Acta Hortic. 431:219-227.

21. Mumford, R. A., Barker, I., and Wood, K. R. 1996. The biology of tospoviruses. Ann. Appl. Biol. 128:159-183.

22. Nono-Womdim, R., Moury, B., Ansan, D., Gognalons, P., GebreSelassie, K., Palloix, A., and Marchoux, G. 1996. Natural and induced variability of tomato spotted wilt virus. Acta Hortic. 431:186-192.

23. Pang, S. Z., Bock, J. H., Gonsalves, C., Slightom, J. L., and Gonsalves, D. 1994. Resistance of transgenic Nicotiana benthamiana plants to tomato spotted wilt and impatiens necrotic spot tospoviruses: Evidence of involvement of the $\mathrm{N}$ protein and $\mathrm{N}$ gene RNA in resistance. Phytopathology 84:243-249.

24. Pang, S. Z., Jan, F. J., Carney, K., Sout, J., Tricoli, D. M., Quemada, H. D., and Gonsalves, D. 1996. Post-transcriptional transgene silencing and consequent tospovirus resistance in transgenic lettuce are affected by transgene dosage and plant development. Plant J. 9:899-909.

25. Pang, S. Z., Jan, F. J., and Gonsalves, D. 1997. Nontarget DNA sequences reduce the transgene length necessary for RNA-mediated tospovirus resistance in transgenic plants. Proc. Natl. Acad. Sci. 94:8261-8266.

26. Pang, S. Z., Nagpala, P., Wang, M., Slightom, J. L., and Gonsalves, D. 1992. Resistance to heterologous isolates of tomato spotted wilt virus in 
transgenic tobacco expressing its nucleocapsid protein gene. Phytopathology 82:1223-1229.

27. Pang, S. Z., Slightom, J. L., and Gonsalves, D. 1993. Different mechanisms protect transgenic tobacco against tomato spotted wilt virus and impatiens necrotic spot tospovirus. Bio/Technology 11:819-824.

28. Parrella, M. P., and Lewis, T. 1997. Integrated pest management (IPM) in field crops. Pages 595-614 in: Thrips as Crop Pests. T. Lewis, ed. CAB International, Wallingford, England.

29. Prins, M., Kikkert, J., Ismayadi, C., de Graauw, W., de Haan, P., and Goldbach, R. 1997. Characterization of RNA-mediated resistance to tomato spotted wilt virus in transgenic tobacco plants expressing NSM gene sequences. Plant Mol. Biol. 33:235-243.

30. Prins, M., Resende, R. d. O., Anker, C., van Schepen, A., de Haan, P., and Goldbach, R. 1996. Engineered RNA-mediated resistance to tomato spotted wilt virus is sequence specific. Mol. Plant-Microbe Interact. 9: 416-418.

31. Qiu, W. P., Geske, S. M., Hickey, C. M., and Moyer, J. W. 1998. Tomato spotted wilt tospovirus genome reassortment and genome segment-specific adaptation. Virology 244:186-194.

32. Robb, K. L., Newman, J., Virzi, J. K., and Parrelia, M. P. 1995. Insecticide resistance in western flower thrips. Pages 341-346 in: Thrips Biology and Management. B. L. Parker, M. Skinner, and T. Lewis, eds. Plenum Press, New York.

33. Schardl, C. L., Byrd, A. D., Benzion, G., Altschuler, M. A., Hildebrand, D. F., and Hunt, A. G. 1987. Design and construction of a versatile system for the expression of foreign genes in plants. Gene 61:1-11.

34. Sherman, J. M., Moyer, J. W., and Daub, M. E. 1998. Tomato spotted wilt virus resistance in chrysanthemum expressing the viral nucleocapsid gene. Plant Dis. 82:407-414.

35. Slightom, J. L., Chee, P. P., and Gonsalves, D. 1992. Field testing transgenic cucumber plants that express the CMV coat protein gene. Pages
753-758 in: Progress in Plant Growth Regulation. C. M. Karssen, L. C. van Loon, and D. Vregdenhil, eds. Kluwer Academic Publisher, Dordrecht, Netherlands.

36. Stoeva, P., Yankulova, M., Nikolaeva, V., Bachvarova, R., Ivanova, L., Maiss, E., Adam, G., Vulkov, V., Guelemerov, S., and Atanassov, A. 1998. Long-term resistance to tomato spotted wilt virus in transgenic tobacco cultivars expressing the viral nucleoprotein gene: Greenhouse and field tests. Mol. Breed. 4:155-164.

37. Thompson, G. J., and van Zijl, J. J. B. 1996. Control of tomato spotted wilt virus in tomatoes in South Africa. Acta Hortic. 431:379-384.

38. Todd, J. W., Culbreath, A. K., and Brown, S. L. 1996. Dynamics and progress of spotted wilt disease relative to insecticide use in peanuts. Acta Hortic. 431:483-490.

39. Tricoli, D. M., Carney, K. J., Russell, F., McMaster, J. R., Groff, D. W., Hadden, K. C., Himmel, P. T., Hubbard, J. P., Boeshore, M. L., and Quemada, H. D. 1995. Field evaluation of transgenic squash containing single and multiple virus coat protein gene constructs for resistance to cucumber mosaic virus, watermelon mosaic virus 2, and zucchini yellow mosaic virus. Bio/Technology 13:1458-1465.

40. Ullman, D. E., Sherwood, J. L., and German, T. L. 1997. Thrips as vectors of plant pathogens. Pages 539-565 in: Thrips as Crop Pests. T. Lewis, ed. CAB International, Wallingford, England.

41. Vaira, A. M., Semeria, L., Crespi, S., Lisa, V., Allavena, A., and Accotto, G. P. 1995. Resistance to tospoviruses in Nicotiana benthamiana transformed with the $\mathrm{N}$ gene of tomato spotted wilt virus: Correlation between transgene expression and protection in primary transformants. Mol. Plant-Microbe Interact. 8:66-73.

42. Whitty, E. B., Hill, R. A., Christie, R., Young, J. B., Lindbo, J. A., and Dougherty, W. G. 1994. Field assessment of virus resistance in transgenic Nicotiana tabacum cv. Burley 49 plants expressing tobacco etch virus sequences. Tob. Sci. 38:30-34. 